\title{
LANDSCAPE AND BIOLOGICAL DIVERSITY OF PROTECTED AREAS NETWORK IN PERM KRAI
}

\author{
S.A. Buzmakov and P.Yu. Sannikov
}

Department of Biogeocenology and Nature Protection,

Perm State National Research University, Perm, Russia

Received 2014-05-26; Revised 2014-10-08; Accepted 2014-10-18

\begin{abstract}
The problem of creating the systems of specially Protected natural Areas (PA) adequately representing the geographical diversity of different territories has been acute. Creation of the territory nature protection systems always requires comprehensive assessment of the representativeness of the existing PA network. In Perm region the only such research was carried out at the end of the last century. Since then, the region borders, structure and PA network size, as well as the structure of natural resource use have significantly changed. In this study we assess the representativeness of the PA network of Perm region. For this purpose the representation of the PA network on landscape and biodiversity was analyzed. The study identified the endowment of natural areas and the representation of wetlands in the PA network in the region. Protected species of plants and animals which need development of measures for the territorial protection were identified. The size of the PAs necessary to develop the nature protection network was calculated.
\end{abstract}

Keywords: Protected Areas (PAs), Landscape Diversity, Biodiversity, Protected Species, Perm Krai

\section{INTRODUCTION}

The problem of creating the systems of PAs representing the geographical diversity of different territories is acute. Creation of the territory nature protection systems always requires comprehensive assessment of the representativeness of the existing PA network. Such work is done at the international level (WWF, IUCN) and at the level of different states and regions (Traba et al., 2007; Jantke et al., 2011; CantúSalazar et al., 2013; Kamei and Nakagoshi, 2006; Trisurat, 2007; Yip et al., 2004). The research carried out by the group of authors and entitled "Protected areas of Russia: Current state and aspects of development" is well-known (Krever et al., 2009). The latest similar research concerning Perm region was done in 1998. It should be emphasized that the work was devoted to Perm region but the territory of the former KomiPermyak Autonomous District (part of Perm region today) was not considered in it.
The Protected Areas (PA) network of Perm region was formed at the end of the 80-s, at the beginning of the 90 -s of the XX century. Since that time a part of protected areas has been eliminated, the borders and size of the others have been changed; the others have become local. Also the composition of protected biological species has changed and finally the structure of Perm region nature management has been changed:

- To determine the necessary size of PAs for Perm region

- To assess the representativeness of the PA network on landscape diversity

- To assess the habitat representativeness of protected species in the PA network

\section{MATERIALS AND METHODS}

To assess the PA network representativeness on landscape diversity we used the long-term studies of PAs Corresponding Author: Sannikov Pavel Yu., Department of Biogeocenology and Nature Protection, Perm State National Research University, 15, Bukireva st., Perm, 614990, Russian Federation 
done by Biogeocenology and Nature Protection Department of Perm State National Research University (PSNRU), forest management data and the Earth remote sensing data (submeter resolution images).

To assess the habitat representativeness of protected species in the PAs network we used the data about the species included in the Red Book of the Russian Federation and Perm region provided by the Ministry of Natural Resources, Forestry and Ecology of Perm region, herbarium materials of Perm University, as well as the data provided by PSNRU Biogeocenology and Nature Protection Department.

Spatial analysis and calculations were done in ArcGIS 9.3 (ESRI).

\section{RESULTS}

\subsection{PA Necessary Percentage}

To assess the geographical diversity representativeness of the territories in PAs we should determine the appropriate proportion of protected areas with respect to the territory as a whole. The percentage of lands recommended for PAs is rather various (Table 1).

The recommended PAs proportions lie in the range of $10-90 \%$. Nowadays the Perm region PAs proportion of the total area is $6,4 \%$. We find it rather reasonable to accept the world average figure equal to $12 \%$ as a necessary portion of protected areas.

\subsection{Representativeness of PAs Network on Landscape Diversity}

The evaluation of landscape representativeness is determined by the presence of natural zones of Perm region in the PAs network.

There are 2 federal protected areas ("Vishersky" and "Basegi" reserves) and 284 regional PAs in Perm Krai at the beginning of 2014. The regional protected areas are presented by protected landscapes (97 items), reserves (20), nature monuments (114), nature reservations (46) and nature-historic parks (5). The reserves, nature monuments and natural reservations have different profiles: Landscape, biological, botanic, zoological, hydrological and geological (Buzmakov and Zaitsev, 2011; Zaitsev, 2011; Buzmakov et al., 2013). In Perm region there are not national and nature parks (PA, 1995).

There are 6 zones in Perm region (the Central Urals, the West Urals, middle and southern taiga, mixed and broadleaved forests and Kungur forest-steppe zone) according to natural zoning (Buzmakov et al., 2011). The distribution of PAs within these zones is shown in Table 2.
The present work is devoted to the regional and federal protected areas of Perm Krai with the exception of biological reserves as they are created to preserve game animals whereas the maintenance of ecological balance is possible due to complex nature protection. Besides, some reserves are similar to other regional PAs in territory.

The PAs size in the middle taiga zone is the biggest$4342,3 \mathrm{~km}^{2}$. The comparable size of PAs is in the Central Urals. The size of PAs in the West and Southern Urals zones is 2976,4 and $1598,5 \mathrm{~km}^{2}$ respectively. The same figure for mixed and broad-leaved forests is slightly more than $567 \mathrm{~km}^{2}$. Kungur forest steppe zone almost does not have PAs as their size is slightly more than $50 \mathrm{~km}^{2}$.

The Central Urals is the most provided with PAs zone $(35,7 \%)$. The middle taiga zone is not enough provided with PAs (10,5\%). The West Urals $(5,0 \%)$, mixed and broad-leaved forests $(2,8 \%)$ and the southern taiga $(1,4 \%)$ are the zones which are less provided with PAs. But Kungur forest steppe is the least provided zone $(0,8 \%)$. Accepting $12 \%$ as a necessary portion of PAs, we receive the minimal territory required for the creation of new protected areas (Table 2).

The next objective is to determine the representation of bogs (as intrazonal formation) in the modern nature conservation network. Bogs are widely spread in Perm region (especially in northern districts) and they are an integral part of natural complexes.

The significant part of PAs includes bogs. So 92 protected areas are totally or partly bog complexes which include small ("Chelvinskoie bog" with the area of 20 hectares) as well as huge PAs ("Big Kama bog" with the area of more than 80 thousands hectares).

There are 4 peatbog zones in Perm region according to the peculiarities of genesis, structure, dominance of various types and frequency of occurrence (Table 3) (Verkhoyarov and Markov, 1976).

The proportion of protected bogs changes according to the zones (Table 3). So, most bogs $(77,37 \%$ ) of Verhne-Kamskiy peatbog zone are included in PAs. About one forth $(26,02 \%)$ of bogs are protected in Sredne-Kamskiy zone and not enough proportion of bogs, slightly more than $11 \%$, is in the protected areas of Priuralskiy mountain and Southern forest steppe zones.

The necessary proportion of protected areas is absolutely maintained in Verhne-Kamskiy and Sredne-Kamskiy zones. For 2 peatbog zones it is necessary to increase the PAs size by 44 and 126 hectares (in Priuralskiy mountain and Southern forest steppe zones respectively). 


\subsection{Habitat Representativeness of Protected Species in PAs Network}

One of the main tasks of PAs network is to conserve species from the Red Book. We should identify the habitat of rare species to assess the role of modern PAs network in biodiversity conservation.

The assessment of representativeness is based on the data about the species included in the Red Book of Perm region, the supplement to Perm region Red Book and the Red Book of the Russian Federation (RBPK, 2008; AST, 2008) (all in all 346 species). The information about protected species habitats was taken from different sources:

- Results of the works revealing the habitats of species included in the Russian Federation Red Book (2000-2013 years)

- Monitoring of the regional protected areas of Perm Krai (2003-2013 years)

- Herbarium materials of PSNRU

- Fund data of PSNRU Biogeocenology and Nature Protection Department

The combined geodata base included information about more than 3,4 thousand of species habitats inscribed in the Red Books of Perm region and the Russian Federation (RBPK, 2008; AST, 2008). Slightly more than a third (1254 habitats $(37,03 \%))$ of identified habitats are in the PAs boarders.

For the assessment all species were divided into several conventional groups:

- Species inhabits everywhere or is widely spread

- Species inhabits PAs

- Species inhabits Perm region but not in PAs

- Species habitats are not identified in Perm region

- No data. The species has not been studied in Perm region

The data about the protected species representativeness in PAs is is summarized in Table 4.

According to some scientists 6 protected species $(1,7 \%)$ inhabit everywhere but their quantity is low. All these species are included in the Russian Federation Red Book, 2 of them are birds (quail (Coturnix coturnix) and landrail (Crex crex) and 4 species of fish (sterlet (Acipenser ruthenus), a taimen (Hucho taimen), a riffle minnow (Alburnoides bipunctatus rossicus) and a freshwater sculpin (Cottus gobio).
Slightly less than a half of the Red Book species (167 species or 48,3\%) inhabit PAs. Among them are an European black-throated loon (Gavia arctica), a peregrine (Falco peregrinus), smooth snake (Coronella austriaca), Crangonyx chlebnikovi (Crangonyx chlebnikovi), feather grass (Stipa pennata), lady's slipper (Cypripedium calceolus), Braun fern (Polystichum braunii), bolet olive-brown (Boletus luridus), geterodermiya (Heterodermia speciosa) and many others.

In general wide spread species and PAs species are 50\% of all protected species. The population of these species is rather stable and they are not in danger of existence.

All the identified habitats for 56 species $(16,2 \%)$ are outside the protected areas. Their location is not supported by the territory protection. Among these species are a grayling (Thymallus thymallus), spadefooted toad (Pelobates fuscus), pale harrier (Circus macrourus), common partridge (Perdix perdix), flea thyme (Thymus ovatus), sickle-fruited astragalus (Astragalusfalcatus), redshank bolet (Boletus luridiformis), blog club-moss (Lycopodium inundatum), brioriya Flemont (Bryoria fremontii) and many others. The major part of these species is included in the main list of the Red Book of Perm region and it is obvious that part of these habitats must have the status of PAs.

The habitats for a part of protected species (20 species or $5,8 \%$ ) have not been identified within the territory of Perm region. About 15 of them ( 7 bird species, 6 species of metasperm plants, 1 species of mammal and 1 fish species) despite their search were not been discovered. Among them are a Russian desman (Desmana moschata), black stork (Ciconia nigra), red-breasted goose (Rufibrenta ruficollis), greater spotted eagle (Aquila clanga), trout (Salmo trutta caspius morfa fario), anemone forcipate (Anemone dichotoma), plain pink (Dianthus campestris), erubescent onion (Allium rubens) and other species.

About 5 other species (4 species of fish and the only representative of Cyclostomes) are not able to inhabit Perm region because of their migratory mode of life. Their habitat in Perm Krai is impossible because of numerous hydroelectric power stations on the Volga and Kama.

Nowadays there is no reliable data about a rather big group of species (97 species or $28,0 \%$ ). All these species (except for one) are included in the supplement to the Red Book of Perm region (RBPK, 2008).

We need additional investigations to determine biological peculiarities and distribution of 117 species (the two last groups). 
All species protected in the territory of Perm region are included in this analysis. Meanwhile, each of 3 lists of species from the Red Book has its own peculiarities (Table 5 to 7 ).

The species from the Red Book of the Russian Federation form a group of extinct species. There is also a group of species which inhabit everywhere or are wide spread. This is explained by the national scale of the list (AST, 2008).

Table 1. Recommended proportion of PAs

\section{Source}

WPC (1992). (Khromov, 2005);

The united nations conference on the convention on biodiversity in nagoya (Japan, 2010 г.) (SCBD, 2010);

The average proportion of protected land areas (according to the international union for conservation of nature) (Dezhkin, 2012); U.S. State Environment Program (Odum, 1986);

North american ecologist eugene odum suggested that there should be at least 2 hectares of protected areas per person (Odum, 1986). Thus, according to the population of Perm region (2 631073 people (2012)) there must be 5262,15 thousand of PAs hectares (32,7\% of Perm region);

Government decree of sverdlovsk region of July 28, 2009 № 865-PP (CESSR, 2009);

Urban development master plan of the city of moscow 2025

(GUPCM, 2009);

Based on the known laws of 1 and $10 \%$, as well as physical and mathematical calculations of the biosphere energy balance by Gorshkov, N.F. Reimers gives the recommended proportion of differentiated PAs on biomes (Reimers, 1994).
The present list of the species from the Red Book of Perm region is characterised by the species habitats outside the PAs (RBPK, 2008).

The present list has been initially formed from the species which are not enough studied and their status should be determined from further investigations. Therefore, the supplement to the Red Book of Perm region includes all species (except one) for which there is no reliable data (RBPK, 2008; AST, 2008) and they need further investigation of their geographical distribution.

Table 2. PAs distribution in natural zones of Perm region

\begin{tabular}{lllll}
\hline Natural zone & PA size $\left(\mathrm{km}^{2}\right)$ & $\begin{array}{l}\text { PA proportion in } \\
\text { natural zone, }(\%)\end{array}$ & $\begin{array}{l}\text { Zone proportion } \\
\text { required for new PAs, }(\%)\end{array}$ & $\begin{array}{l}\text { Necessary increase } \\
\text { of PA size, }\left(\mathrm{km}^{2}\right)\end{array}$ \\
\hline Central Urals & 2976,4 & 35,7 & 0 & 0 \\
West Urals & 1598,5 & 5,0 & 7,0 & 2263,3 \\
Middle taiga & 4342,3 & 10,5 & 1,5 & 618,3 \\
Southern taiga & 744,8 & 1,4 & 10,6 & 5470,6 \\
Mixed and broad-leaved forests & 567,0 & 2,8 & 9,2 & 1891,3 \\
Kungur forest steppe zone & 51,5 & 0,8 & 11,2 & 762,8 \\
Total & 10280,5 & 6,4 & - & 11006,6 \\
\hline
\end{tabular}

Table 3. Bog Representativeness in PAs network

\begin{tabular}{|c|c|c|c|c|}
\hline Peatbog zones & $\begin{array}{l}\text { Bogs area, } \\
\text { (ths. lha.) }\end{array}$ & $\begin{array}{l}\text { Bogs area within } \\
\text { PAs, (ths. Iha.) }\end{array}$ & $\begin{array}{l}\text { Proportion of } \\
\text { protected bogs, }(\%)\end{array}$ & $\begin{array}{l}\text { Bogs area desirable } \\
\text { to be included in PAs } \\
\text { network, ths.lha.) }\end{array}$ \\
\hline Verhne-Kamskiy zone & 380,80 & 294,64 & 77,37 & 0 \\
\hline Priuralskiy mountain zone & 12,79 & 1,49 & 11,65 & 0,04 \\
\hline Sredne-Kamskiy (central) zone & 44,12 & 11,48 & 26,02 & 0 \\
\hline Southern forest steppe zone & 15,14 & 1,69 & 11,16 & 0,13 \\
\hline Total & 452,84 & 309,30 & 68,30 & 0,17 \\
\hline
\end{tabular}


Table 4. Distribution of protected species habitats in the PAs of Perm region

\begin{tabular}{|c|c|c|c|c|c|c|c|}
\hline & $\begin{array}{l}\text { Number of } \\
\text { Species }\end{array}$ & $\begin{array}{l}\text { Identified } \\
\text { habitats }\end{array}$ & $\begin{array}{l}\text { Species inhabits } \\
\text { everywhere }\end{array}$ & $\begin{array}{l}\text { Species } \\
\text { inhabits PAs }\end{array}$ & $\begin{array}{l}\text { No species } \\
\text { habitat in Pas }\end{array}$ & $\begin{array}{l}\text { Species not } \\
\text { identified }\end{array}$ & No data \\
\hline Mammals & 3 & 5 & - & 2 & - & 1 & - \\
\hline Birds & 60 & 376 & 2 & 25 & 10 & 7 & 16 \\
\hline Reptiles & 1 & 3 & - & 1 & - & - & - \\
\hline Amphibians & 3 & 12 & - & 1 & 2 & - & - \\
\hline Bony fishes & 14 & 24 & 4 & - & 5 & 5 & - \\
\hline Cyclostomes & 1 & - & - & - & - & 1 & - \\
\hline Invertebrates & 21 & 29 & - & 11 & - & - & 10 \\
\hline Metasperm & 177 & 2660 & - & 98 & 29 & 6 & 44 \\
\hline Fernies & 16 & 153 & - & 10 & 3 & - & 3 \\
\hline Selaginoides & 2 & 6 & - & 1 & - & - & 1 \\
\hline Lichen & 14 & 56 & - & 5 & 3 & - & 6 \\
\hline Fungi & 34 & 62 & - & 13 & 4 & - & 17 \\
\hline Total & 346 & 3386 & 6 & 167 & 56 & 20 & 97 \\
\hline Proportion (\%) & & & 1,7 & 48,3 & 16,2 & 5,8 & 28,0 \\
\hline
\end{tabular}

Table 5. Species included in the Red Book of the Russian Federation and its supplement which inhabit (inhabited) Perm region

\begin{tabular}{llllllll}
\hline & $\begin{array}{l}\text { Number of } \\
\text { Species }\end{array}$ & $\begin{array}{l}\text { Identified } \\
\text { habitats }\end{array}$ & $\begin{array}{l}\text { Species inhabits } \\
\text { everywhere }\end{array}$ & $\begin{array}{l}\text { Species } \\
\text { inhabits Pas }\end{array}$ & $\begin{array}{l}\text { Species habitat } \\
\text { not identified in Pas }\end{array}$ & $\begin{array}{l}\text { Species not } \\
\text { identified }\end{array}$ & No data \\
\hline Mammals & 1 & 0 & - & - & - & 1 & - \\
Birds & 24 & 139 & 2 & 11 & 4 & 7 & - \\
Bony fishes & 9 & - & 4 & - & - & 5 & - \\
Cyclostomes & 1 & - & - & - & - & 1 & \\
Invertebrates & 5 & 6 & - & 4 & - & - & 1 \\
Metasperms & 22 & 74 & - & 22 & - & - & - \\
Lichen & 4 & 40 & - & 3 & 1 & - & - \\
Fungi & 4 & 6 & - & 4 & - & 14 & 1 \\
Total & 70 & 265 & 6 & 44 & 5 & 20,0 & 1,4 \\
Proportion (\%) & & & 8,6 & 62,9 & 7,1 & & - \\
\hline
\end{tabular}

Table 6. Species included in the Red Book of Perm region

\begin{tabular}{llllll}
\hline \multicolumn{7}{c}{} & & & Species habitat in & \\
& Number of species & Identified habitats & PAs species inhabits & PAs not identified & No data \\
\hline Birds & 14 & 222 & 12 & 2 & - \\
Reptiles & 1 & 3 & 1 & - & - \\
Amphibians & 1 & 4 & - & 1 & - \\
Bony fishes & 3 & 14 & - & 3 & - \\
Invertebrates & 3 & 17 & 3 & 24 & - \\
Metasperms & 62 & 555 & 32 & 2 & - \\
Ferny & 7 & 31 & 5 & 2 & - \\
Lichen & 4 & 16 & 2 & 1 & 6 \\
Fungi & 7 & 18 & 6 & 35 & 5,9 \\
Total & 102 & 880 & 61 & 34,3 & - \\
Proportion $(\%)$ & & & 59,8 & & \\
\hline
\end{tabular}

Table 7. Species are in need of special attitude to their status in the environment (Supplement to the Red Book of Perm region)

\begin{tabular}{|c|c|c|c|c|c|}
\hline & Number of species & Identified habitats & PAs species inhabits & $\begin{array}{l}\text { Species habitat in } \\
\text { PAs not identified }\end{array}$ & No data \\
\hline Mammals & 2 & 5 & 2 & - & - \\
\hline Birds & 22 & 15 & 2 & 4 & 16 \\
\hline Amphibians & 2 & 8 & 1 & 1 & - \\
\hline Bony fishes & 2 & 10 & - & 2 & - \\
\hline Invertebrates & 13 & 6 & 4 & - & 9 \\
\hline Metasperms & 93 & 2031 & 44 & 5 & 44 \\
\hline Ferny & 9 & 122 & 5 & 1 & 3 \\
\hline Selaginoides & 2 & 6 & 1 & - & 1 \\
\hline Lichen & 6 & 0 & - & - & 6 \\
\hline Fungi & 23 & 38 & 3 & 3 & 17 \\
\hline Total & 174 & 2241 & 62 & 16 & 96 \\
\hline Proportion (\%) & & & 35,6 & 9,2 & 55,2 \\
\hline
\end{tabular}




\section{DISCUSSION}

The practice of organization of protected areas in the Perm region during from the early 20th century. However, representative system of protected areas is not yet created. Apparently, work to improve the network of protected areas should be continued permanently. This confirms the fact that such works are constantly held in various regions of the world (Traba et al., 2007; Jantke et al., 2011; Cantú-Salazar et al., 2013; Kamei and Nakagoshi, 2006; Trisurat, 2007; Yip et al., 2004).

The habitats of 117 protected species $(33,8 \%)$ in the Perm region not identified (Table 4). It is an information gap and requires further study. This is confirmed by modern theoretical concepts of GAP analysis (Langhammer et al., 2007).

The next step, after this study, will be list of recommendations to supplement the current network of protected areas. This is evidenced by the experience of previous studies (Krever et al., 2009; Traba et al., 2007; Jantke et al., 2011; Cantú-Salazar et al., 2013).

\section{CONCLUSION}

The necessary proportion of the protected areas for Perm region should not be less than $12 \%$. The area of the existing PAs should be increased by $11006,6 \mathrm{~km}^{2}$.

The representativeness of Perm region natural zones in the PAs network is non-uniform. The central Urals (the proportion of PAs is $35,7 \%$ ) has enough PAs. The creation of the representative PAs network of Perm region demands: The increase of the PAs size in the middle taiga by $10,5 \%$; in the West Urals by $7,0 \%$; in mixed and broad-leaved forests by $9,2 \%$; in the Southern taiga by $10,6 \%$; and in Kungur forest steppe by $11,2 \%$.

The bogs representativeness in the PAs network reveals the necessity to increase the PAs size by 44 hectares in Predurals mountain zone and by 126 hectares in the Southern forest steppe zone to fully preserve the diversity of bogs complexes. The required rate protection for 2 other peat-bog areas (Verhne-Kamskiy and SredneKamskiy zones) is completely observed.

Almost half (167 species or 48,3\%) of the rare species in Perm region are preserved in modern PAs.

The modern level of study of 56 rare species distribution allows to pass to the development of PAs for their conservation.

The level of geographical and biological investigation of 117 species $(33,8 \%)$ is not sufficient and these species need additional research.
About 6 species which are widely spread and do not require special protection measures form a separate group.

\section{ACKNOWLEDGEMENT}

This study was supported by Russian Foundation for Basic Research (project № 14-05-31262). We also expressed gratitude to Professor Sergei Ovesnov for usage of herbarium materials of PSNRU.

The study was sponsored by the RFBR project № 1405-31262.

\section{REFERENCES}

AST, 2008. The Red Book of the Russian Federation (Plants and Fungi). Partnership of scientific publications AST press, ISBN: 5-17-004878-5, pp: 855 .

Buzmakov, S.A. and A.A. Zaitsev, 2011. The state of regional protected areas in Perm Krai. Bulletin of Udmurt University. Series: Biol. Earth Sci., 3: 3-12.

Buzmakov, S.A., A.A. Zaitsev and P.Y. Sannikov, 2011. Allocation the territories, perspective for creation the natural park in Permskiy Krai. Proceed. Samara Sci. Center Russian Acad. Sci., 1: 1492-1495.

Buzmakov, S.A., G.A. Voronov and A.A. Zaytsev, 2013. The characteristics of the state of protected areas of perm Krai. World Applied Sci. J., 22: 956-963. DOI: 10.5829/idosi.wasj.2013.22.07.2999

Cantú-Salazar, L., C.D.L. Orme, P.C. Rasmussen, T.M. Blackburn and K.J. Gaston, 2013. The performance of the global protected area system in capturing vertebrate geographic ranges. Biodiversity Conservat., 22: 10331047. DOI: $10.1007 / \mathrm{s} 10531-013-0467-7$

CESSR, 2009. Government of Sverdlovsk region Decree of July. Conception of Ecological Safety of Sverdlovsk Region up to 2020.

Dezhkin, V.V., 2012. Territory nature protection in the world and Russia.

GUPCM, 2009. Committee for urban development and architecture of the city of Moscow. General Urban Plan of the City of Moscow to 2025.

Jantke, K., C. Schleupner and U.A. Schneider, 2011. Gap analysis of European wetland species: Priority regions for expanding the Natura 2000 network. Biodiversity Conservat. 20: 581-605. DOI: 10.1007/s10531-010-9968-9

Kamei, M. and N. Nakagoshi, 2006. Geographic assessment of present protected areas in japan for representativeness of forest communities. Biodiversity Conservat., 15: 4583-4600. DOI: 10.1007/s10531-005-5822-x 
Khromov, A.V., 2005. The characteristics of the current state of protected areas. Bulletin Astrakhan State Technical University, 4: 13-16.

Krever, V.G., M.S. Stishov and I.A. Onufrenya, 2009. Protected Areas of Russia, Modern State and Prospects. 1st Edn., ISBN-10: 5-7640-0062-9, pp: 455.

Langhammer, P.F., M.I. Bakarr, L.A. Bennun, Brooks, M. Thomas and D.S. Naamal et al., 2007. Identification and Gap Analysis of Key Biodiversity Areas: Targets for Comprehensive Protected Areas Systems. 1st Edn., IUCN, Gland, Switzerland, ISBN-10: 283170992X, pp: 116.

Odum, Y., 1986. Ecology. «Mir» Press, 2: 376-376.

PA, 1995. Federal law of Russian Federation. Protected Areas.

RBPK, 2008. Rare and endangered species of animals and plants. Knizhniy Mir Press, ISBN: 978-5-903861-05-7, pp: 256.

Reimers, N.F., 1994. Ecology (Theories, Laws, Rules, Principles and Hypotheses). 1st Edn., «Molodaya Rossia» Press, ISBN-10: 5-7120-0669-3, pp: 367.

SCBD, 2010. Nagoya protocol on access to genetic resources and the fair and equitable sharing of benefits arising from their utilization to the convention on biological diversity. Secretariat of the Convention on Biological Diversity, United Nations Environment Programme.
Traba, J., E.L.G. Morena, M.B. Morales and F. Suárez, 2007. Determining high value areas for steppe birds in Spain: Hot spots, complementarity and the efficiency of protected areas. Biodiversity Conservat., 16: 3255-3275. DOI: 10.1007/978-1-4020-6865-2_2

Trisurat, Y., 2007. Applying gap analysis and a comparison index to evaluate protected areas in Thailand. Environ. Manage., 39: 235-245. DOI: 10.1007/s00267-005-0355-3

Verkhoyarov, G.N. and V.D. Markov, 1976. Peat Deposits of Perm Region. 1st Edn., Geoltorfrazvedka press, pp: 403.

WPC, 1992. Parks for life: Report of the IVth World Congress on National Parks and Protected Areas. World Parks Congress.

Yip, J.Y., R.T. Corlett and D. Dudgeon, 2004. A fine-scale gap analysis of the existing protected area system in Hong Kong, China. Biodiversity Conservat., 13: 943957. DOI: 10.1023/B:BIOC.0000014463.32427.cf

Zaitsev, A.A., 2011. Transformation of Ecosystems in Protected Areas. Anthropogenic Transformation of Natural Habitat: Proceedings of International School for the Young. 1st Edn., ISBN: 978-5-7944-1779-1, pp: 88-94. 